\title{
Suomalaisen naisyrittäjän historia - ruokaa, vaatteita ja hoivaa
}

\author{
Kirsi Vainio-Korhonen
}

\begin{abstract}
Harva nainen on päätynyt yrittäjäksi koulutuksen kautta. Itsensä työllistäneiden naisten tärkein harjaantumisympäristö on ollut ja on edelleenkin koti taikka palvelustai työpaikka. Naisten yritysstrategiat vaikuttavat samantyyppisiltä 1700-, 1800- ja 1900-luvuilla. Naisyrittäjyys on aina ollut suuria taloudellisia riskejä karttavaa pienyrittäjyyttä.
\end{abstract}

$\mathrm{N}^{\mathrm{a} a}$ aisen asema on Euroopassa muuttunut perin pohjin viimeksi kuluneiden kahden vuosisadan aikana. Naiset ovat saaneet samat juridiset ja poliittiset oikeudet kuin miehet. Hyvinvointivaltion tarjoamat palvelut ja tehokas lapsiluvun rajoittaminen ovat helpottaneet työelämässä olevien naisten taakkaa. Kaksi maailmansotaa toi naisia monille miehisinä pidetyille aloille. Myös koulutusmahdollisuudet ja kaikki ammatit ovat vähitellen avautuneet naisille.

Suurista muutoksista huolimatta tiukka jako naisten ja miesten töihin on pysynyt lähes muuttumattomana. Naiset ja miehet työskentelevät edelleen eri ammateissa, eri tasoilla ja eri työtehtävissä. Useimmat naiset useimmissa yhteiskunnissa tekevät maksua vastaan samoja töitä, joita he ovat tehneet tai tekevät ilmaiseksi kodeissa. Toisin sanoen naisvaltaisimpia ovat alat, joihin liittyviä taitoja harjoitettiin jo vanhastaan palkattomana kotityönä. Jos naiset ja miehet ovat samalla alalla tai samassa työpaikassa, ammatillinen sukupuoliero on usein vertikaalista: miehet työskentelevät johtoportaassa, naiset suorittavassa työssä.

Myös Suomi on viimeksi kuluneiden kahden vuosisadan aikana muuttunut agraaritaloudesta ensin teollistuneeksi ja sitten jälkiteolliseksi yh- teiskunnaksi, samalla kun kaikki naisten kouluttautumiseen ja työntekoon liittyvät esteet on purettu. Suomalaiset naiset saavuttivat jo ennen ensimmäistä maailmansotaa täysivaltaisuuden (naimattomat naiset 1864), elinkeinovapauden (1879) ja äänioikeuden ja vaalikelpoisuuden valtiollisissa vaaleissa (1906).Tästä huolimatta näyttää yhteiskunnan selvä jakautuminen naisten ja miesten alueisiin ja aloihin pysyneen muuttumattomana. Enemmistö suomalaisnaisista työskentelee ns. naisammateisssa. Useimmat naiset hoitavat yhä edelleen palkkaa vastaan lapsia, sairaita ja vanhuksia, ompelevat, siivoavat, laittavat ruokaa, tekevät toimistotyötä, toimivat myyjinä ja harjoittavat kampaajan tai kosmetologin ammattia. Miehet pysyttelevät yhtä tiukasti miehisillä aloilla, raskaassa teollisuudessa, rakentamisessa, koneiden ja laitteiden korjaamisessa ja liikenteessä.

Yrittäjänäkin nykynainen myy, ompelee, paikkaa, leipoo, siivoaa, valmistaa ruokaa ja majoittaa. Näyttäisi siltä, että täsmälleen samaa teki jo hänen edeltäjänsä esiteollisessa yhteiskunnassa, siis ennen 1800-luvun puoltaväliä. 'Yrityskokokin' oli tuolloin yhtä pieni kuin nykysuomessa: valtasosa naisista työllisti vain itsensä. Esimerkiksi 1700-luvun Turussa, joka tuolloin oli Suomen 
suurin kaupunki, oli runsaasti itsensä työllistäviä naisia - siis naisia, joiden tekemä työ oli itsenäistä ja jotka vastasivat itse työhönsä liittyneistä taloudellisista riskeistä. Joukossa oli muutama varakas, merenkulkua, kauppaa tai käsityötä harjoittava porvarisleski, mutta suurin osa naisista ansaitsi elantonsa hyvin pienimuotoisella yritystoiminnalla: pikkurihkaman, käytettyjen huonekalujen ja vaatteiden, hedelmien, vihanneksien, kapakalan, makkaran, leivonnaisien, tupakan, nauhojen, neulojen ja erilaisten asusteiden kaupustelulla, anniskelulla, ruokalanpidolla, majoituspalveluilla, pienten lasten opetuksella, kehruulla, kankaankudonnalla, ompelulla, tekstiilien huollolla ja siivouksella.

$\mathrm{T}$ urun kaupungin tileihin sisältyneissä kaupusteluveron kantoluetteloissa mainitaan kaupustelijoina vuosittain 18-26 naista: merimiesten, kirvesmiesten, ajurien, kengänpaikkaajien, kisällien ja toimestaan eronneiden porvareiden ja sotamiesten vaimoja ja leskiä. Saman suuruinen joukko naisia maksoi erityistä kapakointiveroa myyntiin pannusta oluesta. Monet naislesket pitivät kodeissaan vierasmajaa. Paikallinen sanomalehti kirjasi tarkasti kaikki kaupunkiin saapuneet parempisäätyiset matkamiehet ja -naiset ja heidän vuokraemäntänsä. Matkustajia majoittamalla elantonsa ansaitsivat mm. turkulaisen kapakoitsijan, peruukintekijän, vaununtekijän, ruokatavarakauppiaan ja kirjansitojan leski. Ansiokotiteollisuudella ja käsityöllä tuloja hankkivista naisista oli myös tietoja lehtien palstoilla. He valmistivat ja myivät hattuja, myssyjä, sukkia, käsineitä, naistenvaatteita, kauluksia, paitoja, viuhkoja, sateen- ja päivänvarjoja, tekokukkia ja antoivat nuorille tytöille ompeluopetusta. Vastaavanalaisia 'kääpiöyrittäjiä' löytyy kankurien joukosta: vuonna 1748 kaupunkilaisnaisille taattiin oikeus kutoa myyntin yksinkertaisia pellavakankaita.

Porvarisammattien osalta naisten yrittäjyyden muodollisia esteitä purettiin kautta 1800-luvun, mutta yrittäjyyden sukupuolirakenteissa ei näytä tapahtuneen mitään murtumaa tai muutosta. Suomen naapurimaassa ja entisessä emämaassa Ruotsissa kaikki kaupunkien käsityöammatit ja myös osa kaupunkien kaupasta avautuivat nai- sille vuonna 1846 . Mille aloille naiset suuntautuivat? Leivän, juomien, lihatuotteiden ja vaatteiden valmistus hallitsivat yhä. Ilmeisesti lähes kaikki käsityöaloilla työskennelleet naiset valmistivat elintarvikkeita ja tekstiilituotteita. Ruotsalainen Christine Bladh onkin todennut, että naisten kaupustelu jatkui 1800-luvun lopun vapaammissa oloissa maito-, leipä-, hedelmä-, kukka-, lihaleikkelekaupan-, ompelutarvike- tai kangaskaupanpitona.

Nais- ja miesyrittäjien välinen sukupuoliero ei ole hävinnyt siirryttäessä esiteollisesta yhteiskunnasta nykypäivään.Tilastojen valossa suomalaisten nykynaisten yritykset ovat pieniä, usein kaikkein pienimpiä. Suurin osa niistä on alle yhdeksän henkeä työllistäviä mikroyrityksiä. Vuonna 1995 Suomessa toimi 277300 yrittäjää. Naisia heistä oli 99 500, siis selvä vähemmistö. Yhteistä nais- ja miesyrittäjille oli kaupan keskeinen merkitys. Muuten toimialat eriytyivät toisistaan hyvikin selvästi sukupuolen mukaan tarkasteltuna. Suuri osa naisyrittäjistä työskenteli maataloudessa tai maatalouden liitännäiselinkeinoissa. Tämän lisäksi naiset tarjosivat yhteiskunta-, koulutus-, terveydenhoito-, majoitus- ja ravitsemuspalveluja. Tämänkaltaisista palvelualan yrityksistä yli 60 prosenttia oli naisten omistuksessa. Naisvaltaisin ala oli yhteiskunnalliset ja henkilökohtaiset palvelut: vuonna 1995 koko toimialan yrittäjistä 68 prosenttia oli naisia. Sekä majoitus-ja ravitsemustoiminnan että koulutus ja terveydenhuolto- ja sosiaalipalvelujen yrittäjistä oli 63 prosenttia naisia. Yrittäjäkunnaltaan miesvaltaisimmat alat puolestaan olivat rakentaminen ja kuljetus. Näiden toimialojen yrittäjistä yli 90 prosenttia oli miehiä. Myös teollisuus oli hyvin miesvaltainen yrittäjyyden muoto: naisia alan yrittäjistä oli vuonna 1995 vain neljännes.

\section{Naisyrittäjä teollistuvassa Turussa vuonna 1910}

$\mathrm{M}$ iltä tilanne näyttää jo edellä mainitussa $\mathrm{Tu}$ russa? Millä aloilla kaupungin naisyrittäjät toimivat elinkeinovapauden säätämisen jälkeen vuoden 1900 tienoilla tai lähestyttäessä vuotta 2000? Näyttäisi siltä, että aikaisemmilta vuosisadoilta periytyvä naistyön malli on säilyttänyt 
asemansa: niin vuoden 1910 kuin nykypäivänkin Turussa palkkatyötä tekevien ja itsensä työllistävien naisten käsissä oli ja on ihmisten ruumiillinen ja henkinen hyvinvointi.

Vanhempi tilastollinen materiaali ei erittele yrittäjiä palkansaajista, mutta elinkeinoilmoituksista, veroluetteloista, henkikirjoista ja osoitekalentereista voi kerätä yksityiskohtaisempia tietoja vuonna 1910 Turussa toimineista naisyrittäjistä. Näissä lähteissä mainitaan runsaat tuhat naisyrittäjää eri aloilta. Kaikkein vaatimattomimpia yrittäjiä ei löydy mistään viranomaislähteistä: jos yrittäminen oli hyvin pienimuotoista ja asiakkaat vähäväkisiä, eivät vähäiset yritystulot ylittäneet 800 markan verorajaa eikä elinkeinoilmoitustakaan yleensä tehty.

Suurin osa naisyrittäjistä harjoitti kankaiden, vaatteiden ja kenkien sekä elintarvikkeiden valmistukseen ja myyntiin, hoivatyöhön tai kauneudenhoitoon liittynyttä pienimuotoista liiketoimintaa. Tähän osaan lukeutui peräti yhdeksän kymmenestä naisyrittäjistä. Suurimman yksittäisen naisyrittäjäryhmän muodostivat vähittäiskauppiaat. Joukkoon kuului lähinnä ruokatavaroita myyviä halli- ja torikauppiaita, siirtomaatavarakauppiaita, ruokatavarakauppiata, maitokauppiaita, ompelutarvike-, kangas-, lanka- tai vaate- kauppiaita, kenkäkauppiaista, väkijuomakauppiaista, liha- tai makkarakauppiaita, kahvikauppiaita ja tupakkakauppiaita. Naiset siis myivät niitä tuotteita - elintarvikkeita, lankoja, kankaita ja vaatteita -, joita he valmistivat tai muuten hallitsivat ja käsittelivät kotitalouksissa.

Myyntityön arjessa naisten taidoilla oli kasvava kysyntä. Kun osa elintarvikkeista - esimerkiksi maito - sekä langat, kankaat ja taloustavarat siirtyivät omavaraistalouden piiristä kauppojen myyntitiskeille, tarvittiin näiden tavaroiden kaupassa naisten tietotaitoa. Asiakkaille oli osattava mitata oikea määrä kangasta ja lankaa, ja maitokaupan myyjän oli osattava käsitellä separaattoria, kirnuta ja piimittää. Puhtausvaatimusten tulo kauppoihin lisäsi niin ikään naismyyjien tarvetta. Kaupoissa olivat aiemmin asioineet usein miehet, ja niissä tupakoitiin yleisesti ja syljeskeltiin lattioille. Uusissa hygieenisissä elintarvikeliikkeissä myyjinä, asiakkaina ja usein myös kauppiaina olivat pääasiassa naiset. Uusi siisteyden vaatimus lisäsi liiketilojen siivoustyötä ja oli samalla yksi syy 'luonnostaan' siisteyteen ja tarkkuuteen taipuvaisen naistyövoiman käytön lisääntymiseen.

Kauppiaiden jälkeen toisella tilalla olivat eri alojen käsityöläiset. Naisten osalta ala oli hyvin teks-

Turkulaiset naisyrittäjät vuonna 1910

\begin{tabular}{|lll|}
\hline Toimialat & Lukumäärä & \% \\
\hline Käsityö & 254 & 23 \\
- Teollisuus & 6 & 1 \\
Rakentaminen & - & - \\
Kauppa & & \\
- Tukkukauppa & 7 & 1 \\
- Vähittäiskauppa & 446 & 41 \\
Majoitus ja ravitsemus & 105 & 10 \\
Liikenne & 16 & 1 \\
Rahoitus-, vakuutustoiminta & 1 & $(0,09)$ \\
Pesu-, silitys-, siivoustoiminta & 109 & 10 \\
Koulutus & 9 & 1 \\
Terveyspalvelut & 85 & 8 \\
Muut palvelut & 40 & 4 \\
Toimiala tuntematon & 5 & $(0,4)$ \\
\hline Yhteensä & 1083 & 100 \\
\hline
\end{tabular}




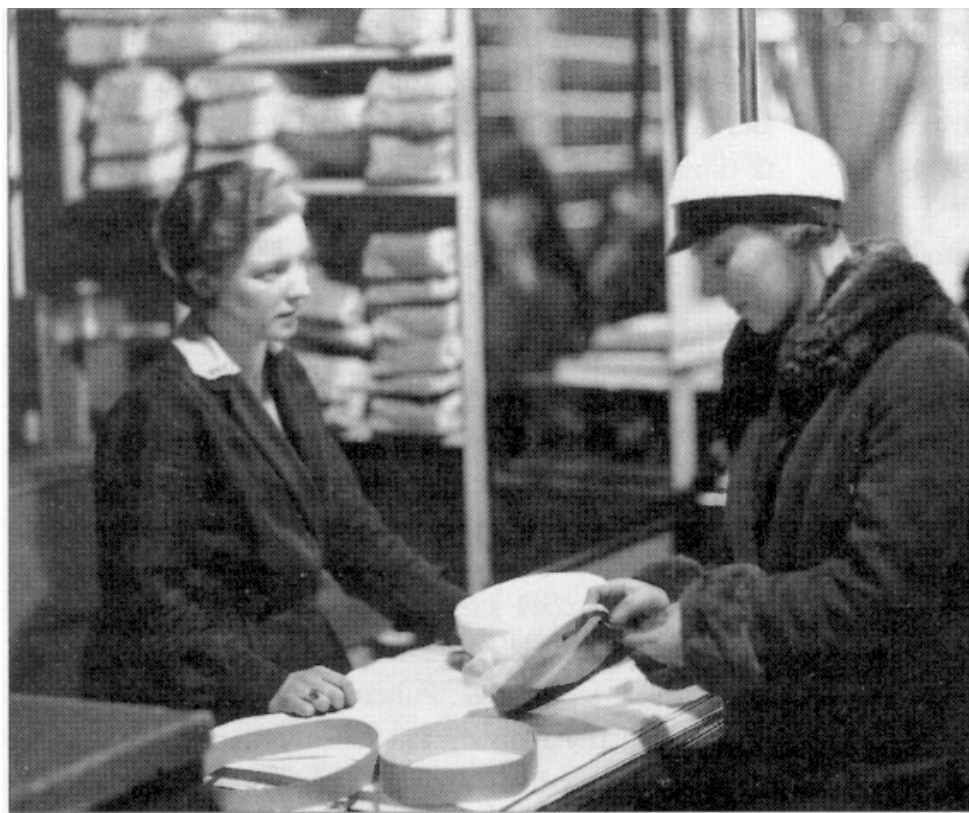

kunnalla tai jopa yksinään. Lähellä ravintola-alaa toimivat myös ne viisi talouskoulun omistanutta naista, jotka oppilaitoksensa yhteydessä ylläpitivät oppilastyövoimalla ruokalaa. Sananmukaisesti yksinäisyrittäjiä olivat ne sairaanhoitajattaret, kätilöt sekä sairasvoimistelijat ja hierojat, jotka myivät palvelujaan yksityisellä terveyssektorilla. Kasvavalla palvelualalla työskenteli myös kampaajia ja partureita, valokuvaajia, saunanomistajia, kasvoja jalkahoitajia, kielenkääntäjiä, konekirjoittajia, taidemaalareita, hautausurakoitsija ja elokuvateatterinomistaja.

Ylioppilaslakkeja valmistavan ja myyvän naisyrittäjän asiakkaana tuore ylioppilasneitonen. Kaksi naisten oppimisen ja pätevöitymisen väylää kohtaavat toisensa tiskin takaa. Kuva vuodelta 1930. Museovirasto.

tiilivaltainen: naiset harjoittivat ammattilaisinakin perinteisiä käsityötaitojaan, kudontaa, ompelua ja leivontaa. Suurimman naiskäsityöläisryhmän muodostivat eri alojen ompelijattaret ja modistit. Heidän lisäkseen käsityöammattien piiriin lukeutui leipojia, kirjansitojia, muutama kello- tai kultasepänliikkeen omistaja sekä yksittäisiä puusepänliikkeiden, maalarinliikkeiden, värjäämöiden, suutarinliikkeiden, kivenhakkaamoiden tai peltisepänliikkeiden omistajia. Miesvaltaisilla käsityöaloilla nainen toimi yleensä käsityöläismiehensä liikekumppanina tai oli perinyt yrityksen edesmenneeltä mieheltään. Vain harvalla naisella oli käsityöyrityksessään palkattuja työntekijöitä. Silloin tällöin liikekumppanina saattoi olla oma sisar.

Ravinto, hoiva ja yrityksen pienuus leimasivat myös niiden naisyrittäjien työtä, jotka toimivat hotelli- ja ravintola-alalla. Enemmälti alaisia oli vain hotellinomistajilla ja ravintoloitsijoilla, kun taas lukuisat höyrylaivaravintoloitsijat - laivamatkustajille myytiin kahvia, teetä, virvoitusjuomia, alkoholia, voileipiä ja pieniä ruoka-annoksia-, ruokalan- tai kahvilanpitäjät ja matkustajakodinomistajat tulivat toimeen pienemmällä henkilö-
Ajurinrattaat ja hevosen omisti 15 naispuolista pika- ja kuorma-ajuria. Nämä naiset eivät kuitenkaan ajaneet itse, vaan palkkasivat hevosenhoitajaksi ja ajajaksi miehen. Myös puhtaanapito työllisti yritteliäitä naisia, pesulanomistajia ja silitttäjiä. Silittäjälle vietiin ennen kaikkea miesten paidat, joita täytyi samalla kovittaa. Myös irralliset kaulukset, mansetit ja rintamukset vietiin mieluummin ammattitärkkärille.

Teollisuusyrityksiä naiset eivät näytä perustaneen yksinään lainkaan. Lähteissä mainitut kolme naispuolista virvoitusjuomatehtailijaa ryhtyivät alalle miestensä liikekumppaneina. Loput naistehtailijoista oli perinyt yrityksensä edesmenneeltä yrittäjämieheltään: kemiallisteknisen tehtaan, viinatehtaan ja etikkatehtaan. Yrittävä nainen oli siis vuoden 1910 Turussa ennen kaikkea pienyrittäjä, joka työllisti itsensä lisäksi korkeintaan muutamia työntekijöitä.

\section{Naisyrittäjä jälkimodernissa Turussa vuonna 1995}

Tuuri päättynyt vuosisata ei tuonut muassaan

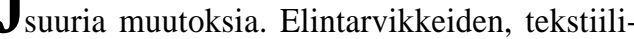
en, hoitotyön ja kauneudenhoidon parissa tehty työ työllisti vielä vuonna 1995 lähes kuusi kymmenestä turkulaisesta naisyrittäjästä. Tuona 
1598 oli naisia. Tästä joukosta 915 naista toimi edellä mainituilla aloilla. Siirtymää kaupasta ja käsityöstä palvelualojen suuntaan oli toki naisyrittäjien keskuudessa tapahtunut vuodesta 1910 ja esimerkiksi käsin tehty ompelutyö on nykyään lähes kokonaan kadonnut ammattiala, mutta yhä edelleen metalli- ja koneteollisuus, rakentaminen ja liikenne ovat useimpien naisyrittäjien ulottumattomissa. Myös voimakkaasti kasvava uusi ala, informaatioteknologia, on hyvin miehistä: vuoden 1995 väestötilaston mukaan turkulaisista alan yrittäjistä 28 oli miehiä ja vain kolme naisia. Jos kaikki palvelualat - kiinteistöalan palvelut, vuokraus ja siivous, koulutus, terveys- ja sosiaalipalvelut sekä muut palvelut - luokitellaan tämän tutkimuksen otsikossa mainitun 'hoivan' piiriin, havaitaankin, että yhä edelleen kolme neljästä turkulaisesta naisyrittäjästä toimii feminiinisesti värittyneillä tekstiili-, elintarvike- ja hoiva-aloilla.

Kauppa tarjosi 1990-luvullakin runsaasti työtilaisuuksia naisyrittäjille: lähes joka neljäs turkulainen naisyrittäjä toimi vuonna 1995 kaupan alalla. Kuten aikaisemminkin etenkin elintarvikkeiden, tekstiilien, pukimien ja kodin sisustukseen liittyvien tavaroiden vähittäiskauppa ja muut pienliikkeet houkuttelivat naisia. Vähittäiskauppaa harjoittavat naiset omistivat päivittäistavarakaupan tai kioskin, myivät lääkkeitä ja terveydenhoitotarvikkeita, kankaita tai lankoja, vaatteita, jalkineita, huonekaluja, kirjoja ja paperia, kukkia sekä koruja ja kelloja. Osa naisista harjoitti torikauppaa. Tukkukauppiailla oli huonekalujen ja tekstiilien agentuureja, ja osa harjoitti ravintoaineiden tukkukauppaa.

Naisten teollisuudenharjoittaminen jatkaa vielä nykyäänkin varhaisempien vuosisatojen pitkää ompelutyön perinnettä. Teollisuuden piirissä toimi vuoden 1995 Turussa 139 naisyrittäjää, joista 70 tekstiiliteollisuudessa. Tärkein naisten teollisuusyrittämisen osa-alue oli vaatteiden valmistus ja turkisten muokkaus. Yksitoista naisyrittäjää toimi elintarviketeollisuudessa, heistä kaksi pehmeän leivän leipojina. Paino-, metalli-, kone- ja huonekaluteollisuusyrityksen omisti yhteensä 30 turkulaisnaista. Ainakin tilastojen valossa näiden naisten yritystoiminta vaikuttaa marginaaliselta: heidät löytää 30-sivuisen väestötilaston kaikkein mitäänsanomattomimmista kategorioista 'muu painaminen', 'muu metallituotteiden valmistus', 'muualla luokittelemattomien kodinkoneiden valmistus', 'muu kulku-

Turkulaiset naisyrittäjät vuonna 1995

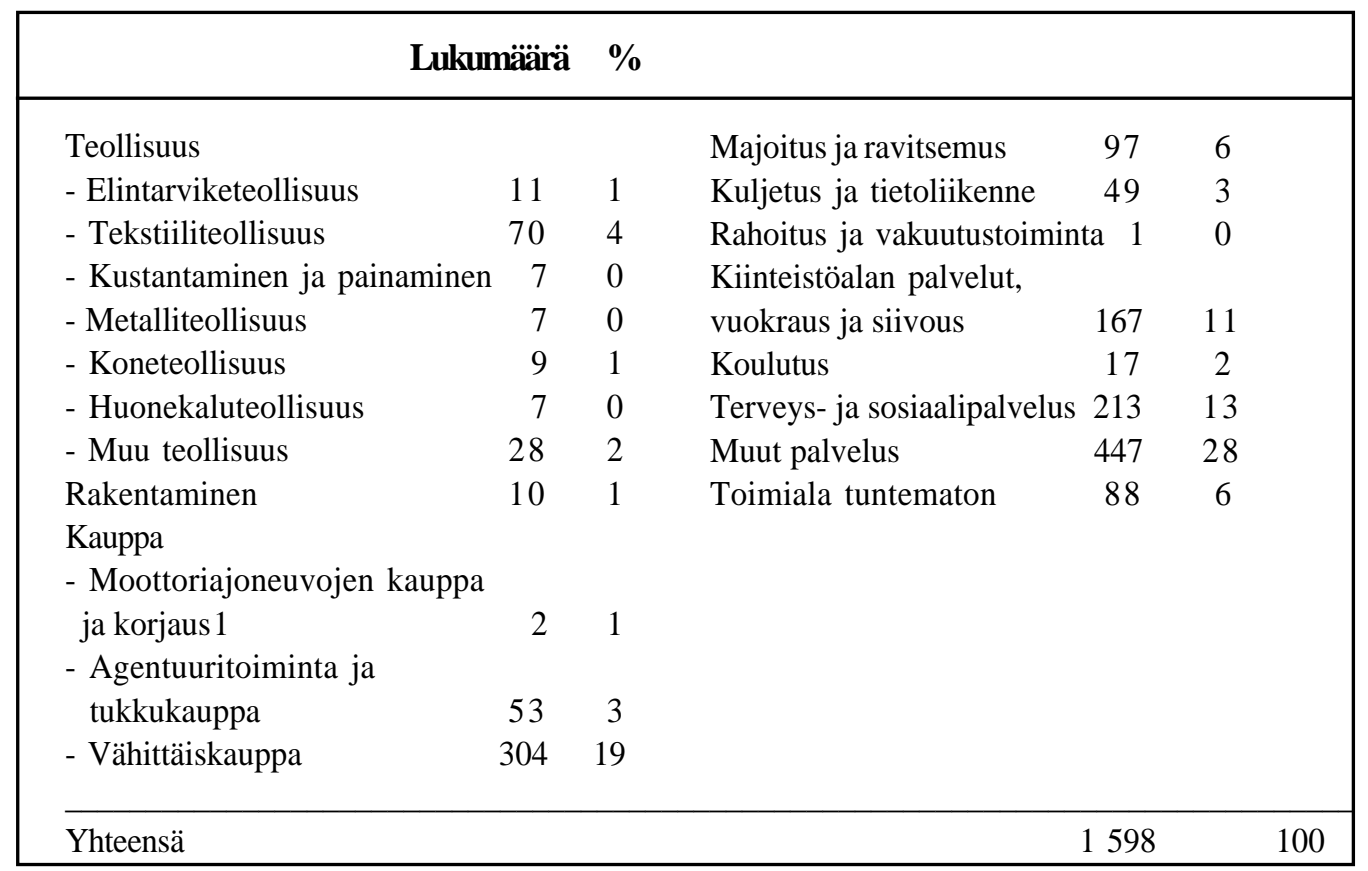


neuvojen valmistus' ja 'muiden huonekalujen valmistus'.

Hotelli- ja ravintola-alalla suosituimpia olivat pienet ruokapaikat ja -kioskit. Näiden naisten omistuksessa oli mm. ravintoloita, ruokakioskeja, kahvi- ja olutbaareja, henkilöstöruokaloita ja ateriapalveluyrityksiä. Kuljetusalan naisryittäminen oli niin ikään pienyrittäjyyttä: neljä viidestä alan naisesta toimi taksiliikenteessä. Kiinteistöalan piirissä suurin naispuolinen yrittäjäryhmä oli siivousyrityksen omistavat naiset. Terveydenhuoltoalan naisyrittäjät tarjosivat lääkäripalveluja, hammashoitopalveluja, fysikaalista hoitoa ja muita terveyspalveluja. Yksi naisista tarjosi yksityisiä eläinlääkintäpalveluja ja ainoastaan kolme naista - nähtävästi kattavan kunnallisen päivähoitojärjestelmän takia - yksityisiä lasten päivähoitopalveluja.

Vähittäiskauppiaiden jälkeen suurin yksittäinen naisyrittäjäryhmä ovat parturit ja kampaajat, vuoden 1995 Turussa 272 naista, jotka taulukossa 2 sijoittuvat ryhmään Muut palvelut. Turkulaisnaiset tarjosivat myös kosmetologi-, solarium- ja pesulapalveluja.Tälläkin osa-alueella naisten omistamat yritykset olivat pieniä: suuri osa työllisti vain itsensä.

\section{Naisyrittäjien oikeudellinen asema ja koulutus 1700- luvulta 1900-luvun alkuun}

$\mathrm{N}^{2}$ aisilla ei ollut 1700-luvulla eikä vielä 1800luvun alkupuolellakaan mitään mahdollisuuksia hankkia muodollista koulutusta. Kauppaa säätelevä lainsäädäntö ei sallinut naisen suorittaa kauppatutkintoa ja päästä sitä tietä itsenäiseksi porvariksi. Vuoden 1734 lain kauppakaaren kolmas kohta edellytti niin ikään, että porvarisoikeuden hakijan tuli olla mies. Holhouksen tai edusmiehisyyden alainen nainen ei voinut vannoa porvarisvalaa, eikä hän täten voinut saada porvarisoikeuksia. Vain leskellä oli lailliset oikeudet hoitaa asiansa itsenäisesti ja siten myös mahdollisuus kuulua porvariselinkeinojen harjoittajien joukkoon. Naisena hän ei kuitenkaan voinut aloittaa uutta, omaa yritystä - kauppakaarihan hyväksyi uusien porvarisoikeuksien hakijoiksi vain miehet - vaan ainoastaan periä puolisonsa oikeudet. Hän toimi siis edesmenneen miehensä vannoman porvarisvalan turvin, ja jos hän meni uudelleen naimisiin, hänestä tuli jälleen vajaavaltainen ja hän menetti oikeutensa harjoittaa elinkeinoa.

Kaupunkien ammattikuntien alainen käsityö oli niin ikään mestarien leskiä lukuunottamatta naisilta suljettua elinkeinotoimintaa. Järjestelmä oli itseään uusintava, koska vain miehille sallittu ammattikoulutus ylläpiti ja laillisti aukottomasti miesten yksinoikeuden käsityöammatteihin. Samalla se takasi miehille kaiken sen vallan, joka kaupunkiyhteisössä oli kytketty porvariuteen, porvarinvalaan ja porvarissäätyyn. Nainen ei voinut edes miehensä verstaan perineenä leskenä saada omalle nimelleen kirjoitettua mestarinkirjaa, ei vannoa porvarinvalaa eikä käyttää porvariuteen kuulunutta poliittista valtaa. Ammattikuntien kokouksissa hän ei ollut samanarvoinen jäsen kuin miehet eikä sen takia yleensä ollut paikalla yhteisistä asioista päätettäessä.

Laki ei kuitenkaan estänyt naiselta kaikkea itsenäistä toimintaa. Aviomiehen edusmiehisyys ja naimattoman naisen holhous koskivat ennen kaikkea kiinteän omaisuuden hallintaa ja yhteiskunnallisen vallan käyttöä - porvarisoikeushan teki haltijastaan myös poliittisen toimijan. Nainen oli muuten oikeustoimikelpoinen ja vastasi itse esimerkiksi omista rikoksistaan. Naimaton nainen sai itse solmia työsopimuksia - pestautua esimerkiksi piiaksi - ja hallita ansaitsemaansa tuloa. Laki salli elannon tarpeessa olevan naisen valmistaa ja kaupustella - ilman porvarisoikeuksia - pikkurihkamaa ja elintarvikkeita. Naiset saattoivat toimia myös ravintoloitsijoina ja ruokalanpitäjinä: aloja ei luettu porvarisammattien joukkoon. Vuokralaisten otto, matkustavaisten majoittaminen tai vaikkapa pensionin pito tarjosivat tuloja yritteliäille naisille.

Näillä naisilla ei yleensäkään ollut yhtä ainoaa, koko aikuisiän kestävää tointa, ja heidän kouluttautumisensa oli satunnaista ja suunnittelematonta. Miehille oppiminen - esimerkiksi kauppaporvariksi tai käsityöläiseksi - oli kotitaloudesta irtautunut, erillinen prosessi, ja he har- 
jaantuivat ammatteihin, joihin he eivät useinaan olleet lapsuudessa tutustuneet. Useimmat naiset sen sijaan toimivat aloilla, jotka olivat heille tuttuja lapsesta lähtien. He ansaitsivat niillä taidoilla ja tiedonmurusilla, joita he kotona tai palveluspaikoissa saivat: kehruulla, kudonnalla, ompelulla, leipomisella ja alkeisopetuksella. Alat olivat usein samat kuin mitä naisten tekemä palkkatyö oli ollut jo vuosisatojen ajan.

Autonomian ajalla naisten mahdollisuudet toimia ja saada koulutusta laajenivat radikaalisti. Naimattomat, 25-vuotta täyttäneet naiset saivat täysivaltaisuuden vuonna 1864, ja naisille ja miehille oli säädetty yhtäläinen perintöoikeus vuonna 1878. Käsityöammattien harjoittamista rajoittanut ammattikuntapakko oli purettu vuonna 1868 ja molempia sukupuolia koskeva elinkeinovapaus saavutettu vuonna 1879 . Vuonna 1889 naimisissa olevat naiset saivat oikeuden hallita työllään ansaitsemaansa tuloa ja oikeuden tehdä itsenäisesti sopimusvelkaa, vaikka he muutoin pysyivätkin miestensä edusmiehisyyden alaisuudessa. Vuonna 1901 naiset saivat opiskeluoikeuden yliopistoissa samoilla ehdoilla kuin miehet ja vuonna 1906 sekä naiset että miehet äänioikeuden ja vaalikelpoisuuden valtiollisissa vaaleissa. Autonomian ajan lopun suomalaisnaiset voivat siis harjoittaa liiketoimintaa likipitäen samoista oikeudellisista lähtökohdista kuin miehet ja ilman kiertoteitä.

Käytännössä muutokset eivät kuitenkaan olleet suuria. Suomen ensimmäinen kauppakoulu perustettiin Turkuun jo vuonna 1839, ja ensimmäiset tekniset reaalikoulut alkoivat seuraavalla vuosikymmenellä. Helsingin polytekninen koulu aloitti toimintansa vuonna 1872. Naisten kouluttautuminen liike-elämän palvelukseen oli kuitenkin vähäistä vielä 1900-luvun alussakin. Ammatillisissa kouluissa naispaikkoja oli lähinnä kauppallisissa oppilaitoksissa ja kotitalous- ja käsityökouluissa. Käsityöläisverstaiden oppisopimuskoulutus oppipojasta kisälliyden kautta mestariksi pysyi miespuolisten työntekijöiden yksinoikeutena, vaikka mitään muodollisia esteitä naisten opinnoille ei enää vuoden 1868 jälkeen ollut. Esimerkiksi leipomoissa oppisopimuspaikat olivat vielä 1900-luvun alkupuolellakin käy- tännössä miehille varattuja. Naispuoliset työntekijät olivat suorittaneet vain poikkeustapauksissa kolmivuotisen oppiajan. Ompelijattarista vain muutamilla oli ammattikoulusivistys. Osa oli suorittanut kuukaudesta kuuteen kuukauteen vaihtelevan palkattoman tai jopa maksullisen oppiajan, mutta useat olivat vain tehneet ompelutyötä pienestä palkasta apulaisina siitä päivästä alkaen, jolloin tulivat ensimmäiseen työpaikkaansa. Opissaolokin tarkoitti tavallisesti sitä, että annettiin työ ja neula käteen ja sanottiin mitä piti tehdä. Mitanottamista, leikkaamista tai sovittamista ei yleensä opetettu lainkaan.

Harva nainen siis päätyi yrittäjäksi koulutuksen kautta. Alansa ammattiopintoja olivat tiettävästi suorittaneet vain sairaanhoitajat, sairasvoimistelijat, kätilöt, hammaslääkärit, koulunomistajat, taiteilijat, kampaajat, kasvohoitajat ja jokunen ompelijatar. Muutoin itsensä työllistäneiden naisten tärkein harjaantumisympäristö oli edelleenkin koti taikka palvelus- tai työpaikka. Niistä harvoista turkulaisnaisista, jotka elinkeinoilmoitusta tehdessään olivat ilmoittaneet itselleen jonkin ammatin eivätkä siis esiintyneet pelkkinä neiteinä, vaimoina tai leskinä, vain ompelijattaret ja modistit olivat poikkeuksetta työskennelleet samalla alalla ennenkin. Ruokalanpitäjiksi sen sijaan ilmoittautui palvelijattaria ja sairaanhoitajattaria, parturiksi kauppa-apulainen ja kauppiaiksi neljän kauppa-apulaisen ja kassanhoitajan ohella ompelijattaria, palvelijattaria, ”työntekijättäriä”, kahvilanpitäjiä ja puhtaaksikirjoittaja, matkustajakodinpitäjäksi siivoojatar, kansankeittiönpitäjäksi silittäjätär ja leipojattariksi kauppias ja ompelijatar.

\section{Ruokaa, vaatteita ja hoivaa vuosisadasta toiseen - miksi?}

【ähes kaikissa yhteisöissä ja kaikkina aikoina kodinhoito, lastenhoito, sairaanhoito, pienten lasten opetus ja tekstiilien valmistus. Agraariyhteiskunnassa nainen viljeli, säilöi sadon, valmisti ruuan, kehräsi, kutoi, ompeli, huolehti sairaista ja synnyttävistä, kasvatti lapset ja sisusti kodin. Oman aikamme nainen tekee palkkatyötä samoilla aloilla elintarvike-ja vaatetusteollisuu- 
dessa, ravintoloissa, hotelleissa, lääkäreinä, sairaanhoitajina, kätilöinä, lastenhoitajina, opettajina ja siivoojina.

Vielä nykyäänkin naisen ammatillinen liikkumavara on keskimääräistä kapeampi, heidän ammatillinen asemansa matalampi ja palkkatasonsa alhaisempi kuin miehillä. Nämä piirteet olivat tyypillisiä naisten tekemälle työlle jo keskiajalla ja että ne ovat säilyneet pääpiirteiltään muuttumattomina vuosisadasta toiseen. Sukupuoleen liitetyt ominaisuudet myös 'tarttuvat'. Jos jokin miehinen ammattiala naisistuu, palkat ja status laskevat. Jos mies tulee työhön naisten alalle, hän nousee nopeasti huipulle, kuin kerma pinnalle.

Myös perheen sisäinen työnjako on säilynyt muuttumattomana: miehen työ on edelleen etusijalla ja parhaiten näkyvissä. Esiteollisessa perheessä elannon hankkiminen vaati kaikkien perheenjäsenten työpanoksen, mutta resurssit olivat viime kädessä miesten hallussa. Nykyperheet ovat rakenteeltaan hyvin vaihtelevia ja joustavia, mutta jos perheessä asuu aikuinen mies, taloudellinen päätöksenteko ja asuinpaikan valinta rakentuvat yhä edelleen miehen työn varaan ja hänen uratoiveidensa ehdoilla. Lapsiperheissä naiset mahdollistavat miestensä kokopäivätyön, koska yleensä he jäävät tarvittaessa kotiin hoitamaan lapsia tai ainakin huolehtivat päivähoitojärjestelyistä.

Naisyrittäjyyttäkin naistyön mallit ja kodin ja perheen asettamat vaatimukset ovat muokanneet ja ohjailleet monella tavalla. Naisyrittäjät ovat ainakin Suomessa ja muissa Pohjoismaissa - meidän aikoihimme asti toimineet ns. naisaloilla, ja samalla naisyrittäjyys on aina ollut leimallisesti suuria taloudellisia riskejä karttavaa pienyrittäjyyttä. Naisten taloudellista toimintaa eivät kahlitse enää muodolliset esteet, mutta yrittäjyyden sukupuolirakenteet eivät ole muuttunet eikä sukupuoliero ole kaventunut juuri lainkaan. Yhteiskuntamme jakautuu niin tässä kuin monessa muussakin suhteessa selkeästi miesten ja naisten alueisiin.Yllättävintä ehkä kuitenkin on se, että vielä nykysuomessakin naisten yritysstrategiat vaikuttavat karkeasti ottaen samanlaisilta kuin 1700-ja 1800-luvuilla tai 1900-luvun alussa.
Syitä on nähtävästi haettava jo naisten kasvatuksesta ja ainakin heidän opinnoistaan. Vielä nykyäänkin suomalaisten naisten enemmistö valitsee palvelu- tai hoitoaloille tähtäävän koulutuksen. Vuonna 1996 hoitoaloille, opettajan työhön, humanistisille aloille ja kauppa- ja toimistoalalle koulutetuista enemmistö oli naisia, kun taas miesvalta hallitsi maa- ja metsätaloudessa, liikenteessä sekä teknisillä ja luonnontieteellisillä aloilla. Työntekijöinä nämä naiset työskentelevät julkisella sektorilla ja palveluammateissa. Yritysideakin löytyy usein samoilta aloilta tai mahdollisesti rakkaan harrastuksen parista.

Yrittäjyyden sukupuolieron taustalla on koulutuksen ohella muitakin syitä. Tiedämme, että vielä nykyäänkin naisyrittäjät ottavat miehiä enemmän huomioon kodin, perheen ja lastensa tarpeet - usein omien tulojensa ja uratoiveidensa kustannuksella. Naiset eivät myöskään vaaranna perheen omaisuutta; harvat suomalaisnaiset antavat esimerkiksi kotinsa yrityslainansa vakuudeksi. Naisilla on yleensä myös vähemmän henkilökohtaista omaisuutta ja pienemmät tulot kuin miehillä. Pääomaköyhät palvelualat ja pienyrittäjyys ovat ehkä tästäkin syystä naisille houkuttelevampi ja vähemmän riskialtis vaihtoehto.

Sukupuolella on suuri merkitys yrittäjien valinnoille, ja monet yritystoiminnassa havaittavat erot voidaan nähdä sukupuolierosta johtuviksi. Naiseuteen ja mieheyteen liitetyt ominaisuudet vaihtelevat eri kulttuureissa ja eri aikoina, mutta kaikki yhteiskuntajärjestelmät jäsentyvät tavalla tai toisella sukupuolierosta käsin. Sukupuoliodotukset ohjaavat syntymästä lähtien ihmisen elämänkulkua. Sukupuolella oli ja on merkitystä myös silloin, kun mies tai nainen ryhtyi tai ryhtyy yrittäjäksi. Yhä edelleen yrittäjän toimiala, yrityksen koko ja kasvutavoitteet korreloivat voimakkaasti hänen omalle sukupuolelleen leimallisten yrittäjämallien ja -strategioiden kanssa.

\section{Arkistolähteet}

TURUN MAAKUNTA-ARKISTO

Turun poliisilaitoksen arkisto:

Luettelot pika- ja kuorma-ajureista

Henkikirjakortisto 


\section{TURUN KAUPUNGINARKISTO}

Turun kaupungin maistraatin ja raastuvanoikeuden arkisto:

Rahatoimikamarin pöytäkirjat

Maistraatin anomusdiaarit

Maistraatin allegaatit

Raastuvanoikeuden konkurssiasiakirjojen luettelot

Kunnalliskertomukset

Kunnallisveroluettelot

Henkikirjat

\section{TURUN KÄRÄJÄOIKEUDEN ARKISTO}

Turun elinkeinoilmoitukset

Luettelo lopetetuista elinkeinoista

Painettu lähdekirjallisuus ja tilastot

Modée, R.G., Utdrag utur ... Publique Handlingar, Placater, Förordningar, Resolutioner och Publicationer IXIV. Stockholm 1742-1804.

Suomen kauppa- ja teollisuuskalenterit 1909 ja 1911. Suomen tilastollinen vuosikirja 1997.

Suomen Virallinen Tilasto (SVT) VI: Väestötilastoa 44,47 ja 48.

Suomen Virallinen Tilasto (SVT) 1998: Väestölaskenta 1995 sekä väestölaskennan tiedoista tuotettuja Turkua koskevia taulukoita.

Turun osoitekalenteri 1910-1911.

\section{Kirjallisuus}

ALLEN, Sheila and Truman, Carole, Women and men entrepreneurs: Life strategies, business strategies. In Allen Sheila and Truman, Carole (eds) Women in business: Perspectives on women entrepreneurs. Routledge: London and New York 1993.

BENNET, Judith M., Medieval Women, Modern Women: Across the Great Divide. In Culture and History 1350-1600. Ed. David Aers. Harvester Wheatsheaf: New York 1992.

BLADH, Christine, Kvinna med eget företag - från 1700-talets mitt till 1800-talets slut. In Hagman, Ingrid (ed.), Mot halva makten - elva historista essäer om kvinnors strategier och mäns motstånd. SOU 1997:113. Stockholm 1997.

BRADLEY, Harriet, Men's Work, Women's Work: A Sociological History of the Sexual Division of Labour in Employment. University of Minnesota Press: Minneapolis 1989

CHELL, Elisabeth, The Entrepreneurial Personality: A Review and Some Theoretical Developments. In Curran, J. - Stanworth, J. - Watkins, D. (eds), The Survival of the Small Firm. Vol 1. The Economics of Survival and Entrepreneurship. Gower: Aldershot 1986

GRIPENBERG, Aleksandra, Suomen naisen oikeustila. Teoksessa Oma maa V. Werner Söderström Osakeyhtiö: Porvoo 1910.

HAKIM, Catherine, Occupational Segregation: A comparative study of the degree and pattern of the differentiation between men and women's work in Britain, the United States and other countries. Research Paper No 9. Department of Employment 1979.

HENTILÄ, Marjaliisa, Keikkavaaka ja kousikka. Kau- pan työ ja tekijät 1800-luvulta itsepalveluaikaan. Edita: Helsinki 1999.

HIETANIEMI, Leena, Tuulen suunta kääntynyt suomalaiselle yrittäjäkunnalle? Teoksessa Eeva-Sisko Veikkola (toim.), Onko huipulla tyyntynyt. SVT Työmarkkinat 1999:12. Tilastokeskus: Helsinki 1999.

HIRDMAN, Yvonne, Genussystemet. In Demokrati och makt i Sverige. Maktutredningens huvudrapport. SOU 1990:44. Stockholm 1990.

HJELT, Vera, Tutkimus koskeva ompelijattarien ammattioloja Suomessa. Työtilasto VI. Helsinki 1908.

HUDSON, Pat and Lee, W. R., Women's Work and the Family Economy in Historical Perspective. In Women's Work and the Family Economy in Historical Perspective. Manchester University Press: Manchester and New York 1990.

HUNT, Margaret R., The Middling Sort: Commerce, Gender and the Family in England 1680-1780. University of California Press: Berkley, Los Angeles and London 1996.

KOVALAINEN, Anne, At the Margins of the Economy: Women's Self-Employment in Finland 1960-1990. Publications of the Turku School of Economics and Business Administration: Turku 1993.

MELKAS, Helinä and Anker, Richard, Gender equality and occupational segregation in Nordic labour markets. International Labour Office: Geneva 1998.

Naiset ja miehet Suomessa 1998. Sukupuolten tasaarvo 3. Tilastokeskus: Helsinki 1998, 33.

NAVARRA, Virginia, Women's Work, Men's Work: Ambivalence of Equality. Marion Boyars Publishers Ltd: London and Boston 1980.

QVIST, Gunnar, Kvinnofrågan i Sverige 1809-1846: Studier rörande kvinnans näringsfrihet inom de borgerliga yrkena. Scandinavian University Books: Göteborg 1960.

SNELLMAN, G. R., Tutkimus Suomen leipurinammatista. Työtilasto III. Teollisuushallitus: Helsinki 1905 .

SNELLMAN, G. R., Tutkimus vähempivaraisten asunto-oloista vuonna 1905 Turun kaupungissa sekä viereisissä Kaarinan ja Maarian pitäjäin osissa. Turun kaupunki: Turku 1906.

SUNDIN, Elisabet - Holmqvist, Carin, Kvinnor som företagare. Liber: Malmö 1989.

ROBERTS, Elisabeth, A Woman's Place. An Oral History of Working-Class Women 1890-1940. Basil Blackwell: Oxford and New York 1985.

VAINIO-KORHONEN, Kirsi, Kvinnliga företagare i Finland: En historia on mat, kläder och omsorg. In Forum för ekonomi och teknik 5/1999

VAINIO-KORHONEN, Kirsi, Käsin tehty - miehelle ammatti, naiselle ansioiden lähde. Käsityötuotannon rakenteet ja strategiat esiteollisessa Turussa Ruotsin ajan lopulla. Historiallisia Tutkimuksia 200. Suomen Historiallinen Seura: Helsinki 1998.

VAINIO-KORHONEN, Kirsi, Mamselli Falckin tarina eli kaupunkihistorian tutkimaton sukupuoli. In Ihmiset ovat kaupunki. Turun Historiallinen Arkisto 53. Turun Historiallinen Yhdistys: Turku 1999.

Artikkeli saapui toimitukseen 20.3.2001. Se hyväksyttiin julkaistavaksi 25.4. 